\title{
OPERATIONAL ART IN THE SINO-VIETNAMESE WAR
}

\author{
A Monograph \\ by \\ MAJ Jason H. Rosenstrauch \\ United States Army
}

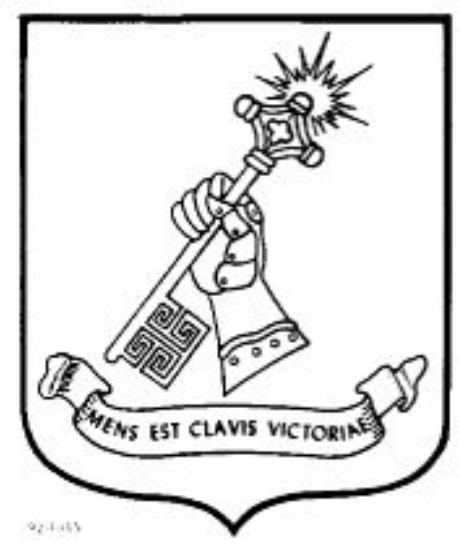

School of Advanced Military Studies

United States Army Command and General Staff College

Fort Leavenworth, Kansas

AY 2014-002 


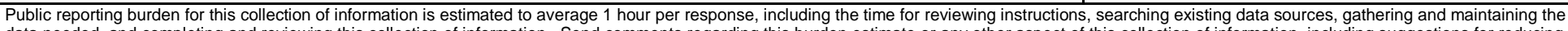

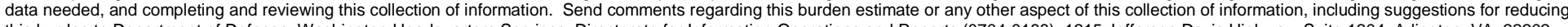

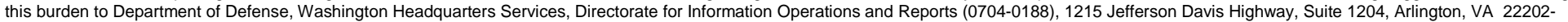

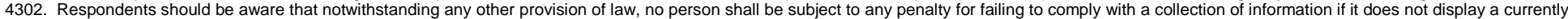
valid OMB control number. PLEASE DO NOT RETURN YOUR FORM TO THE ABOVE ADDRESS.

\begin{tabular}{l|l|l} 
1. REPORT DATE (DD-MM-YYYY) & 2. REPORT TYPE & 3. DATES COVERED (FrOm - TO)
\end{tabular}

12-04-2014

SAMS Monograph

JAN 2014-DEC 2014

4. TITLE AND SUBTITLE

Operational Art in the Sino-Vietnamese War

5a. CONTRACT NUMBER

5b. GRANT NUMBER

5c. PROGRAM ELEMENT NUMBER

6. AUTHOR(S)

5d. PROJECT NUMBER

MAJ Jason H Rosenstrauch

5e. TASK NUMBER

5f. WORK UNIT NUMBER

7. PERFORMING ORGANIZATION NAME(S) AND ADDRESS(ES)

School of Advanced Military Studies (SAMS)

8. PERFORMING ORGANIZATION REPORT

201 Reynolds Avenue

Fort Leavenworth, KS 66027-2134 NUMBER

9. SPONSORING I MONITORING AGENCY NAME(S) AND ADDRESS(ES)

Command and General Staff College

731 McClellan Avenue

Fort Leavenworth, KS 66027-1350

10. SPONSOR/MONITOR'S ACRONYM(S)

CGSC

11. SPONSOR/MONITOR'S REPORT NUMBER(S)

12. DISTRIBUTION / AVAILABILITY STATEMENT

Approved for Public Release; Distribution Unlimited

\section{SUPPLEMENTARY NOTES}

\section{ABSTRACT}

After forming in 1949, the People's Republic of China fought four land campaigns to reassert its regional power. The SinoVietnamese War in 1979 was the fourth and last of these campaigns and escapes notice as both adversaries attempt to downplay the war's history. Historians typically criticize China for failing to dominate its smaller neighbor and achieve its objectives in the War. This study challenges the criticisms of China and analyzes how the People’s Liberation Army achieved strategic objectives and changed the regional power structure through the theoretical framework of operational art. The proposed thesis was China conducted operational art by arranging tactical actions to achieve strategic objectives in the SinoVietnamese War.

This study concluded that Chinese leadership viewed regional alliances as external vulnerabilities that required action. This study also concluded that China conducted operational art, primarily through the appropriate use of tempo, operational reach and simultaneity. In addition, the study found the People's Liberation Army did not find the use of depth appropriate in a war with limited obiectives.

15. SUBJECT TERMS

Operational Art, Sino-Vietnamese War

\section{SECURITY CLASSIFICATION OF:}

\section{a. REPORT}

Unclassified b. ABSTRACT Unclassified c. THIS PAGE

Unclassified
17. LIMITATION OF ABSTRACT

UU

\begin{tabular}{|c|c|} 
18. NUMBER \\
OF PAGES \\
44
\end{tabular}

19a. NAME OF RESPONSIBLE PERSON Jason H. Rosenstrauch 19b. TELEPHONE NUMBER (include area code)

913-758-3302 


\title{
MONOGRAPH APPROVAL
}

Name of Candidate: MAJ Jason H. Rosenstrauch

Monograph Title: $\quad$ Operational Art in the Sino-Vietnamese War

Approved by:

Bruce E. Stanley, PhD

, Monograph Director

James W. MacGregor, COL, FA

, Seminar Leader

Henry A. Arnold III, COL, IN

, Director, School of Advanced Military Studies

\author{
Henry A. Arnold III, COL, IN
}

Accepted this $4^{\text {th }}$ Day of December 2014 by:

Robert F. Baumann, Ph.D.

, Director, Graduate Degree Programs

The opinions and conclusions expressed herein are those of the student author and do not
necessarily represent the views of the U.S. Army Command and General Staff College or any
other government agency. 


\begin{abstract}
Operational Art in the Sino-Vietnamese War, by MAJ Jason H. Rosenstrauch, US Army, 44 pages.

After forming in 1949, the People's Republic of China fought four land campaigns to reassert its regional power. The Sino-Vietnamese War in 1979 was the fourth and last of these campaigns and escapes notice as both adversaries attempt to downplay the war's history. Historians typically criticize China for failing to dominate its smaller neighbor and achieve its objectives in the War. This study challenges the criticisms of China and analyzes how the People's Liberation Army achieved strategic objectives and changed the regional power structure through the theoretical framework of operational art. The proposed thesis was China conducted operational art by arranging tactical actions to achieve strategic objectives in the Sino-Vietnamese War.

This study concluded that Chinese leadership viewed regional alliances as external vulnerabilities that required action. This study also concluded that China conducted operational art, primarily through the appropriate use of tempo, operational reach and simultaneity. In addition, the study found the People's Liberation Army did not find the use of depth appropriate in a war with limited objectives.
\end{abstract}




\section{Contents}

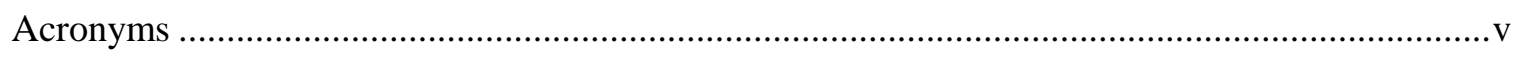

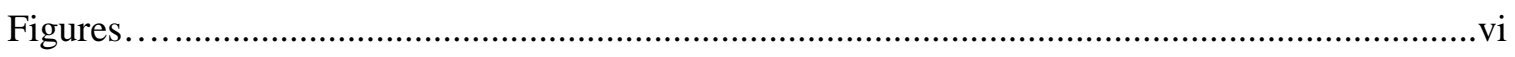

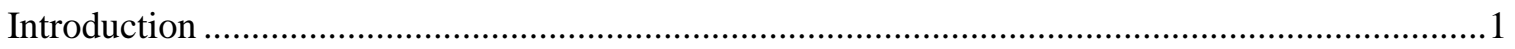

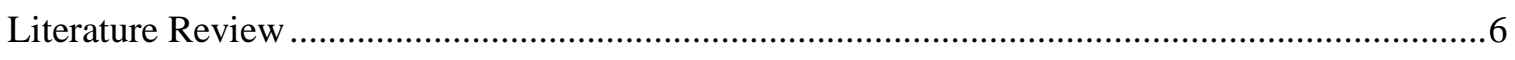

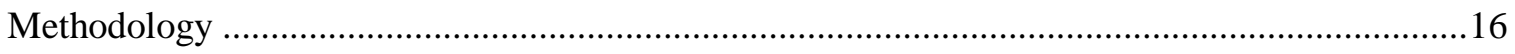

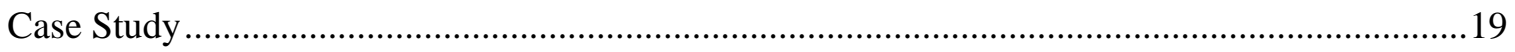

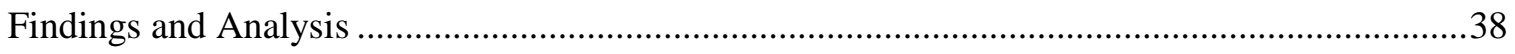

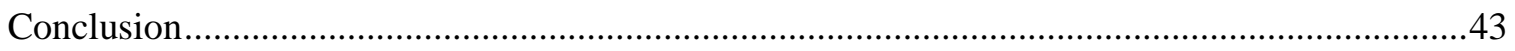

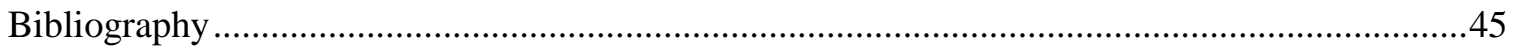




\section{Acronyms}

HWY Highway

LOA Limit of Advance

PLA People’s Liberation Army

PAVN People’s Army of Vietnam

PRC People's Republic of China 


\section{Figures}

Figure 1. Terrain of Northern Vietnam .................................................................................22

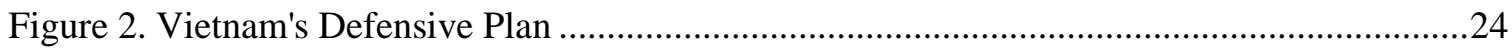

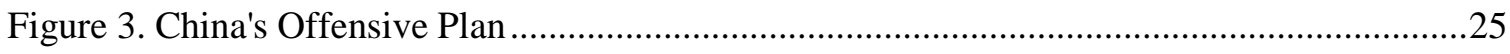




\section{Introduction}

In 1979, China and Vietnam clashed in a violent conflict known in the west as the SinoVietnamese War. Until recently, the world has all but ignored the conflict. Chinese and Vietnamese officials purposefully removed references to the war in historical records and downplayed its impact on their relations. ${ }^{1}$ In February 2014, the Vietnamese government even staged dancing demonstrations to deter its citizens from protesting the Chinese attack on the War's $35^{\text {th }}$ Anniversary. Outside the region, western accounts of the war are mostly in the footnotes of military histories on other topics. Most accounts of the war agree that China lost this one-month conflict with Vietnam and that the two did not resolve the reason for the war until they normalized relations in 1991. However, events in May 2014 challenged the narrative that the conflict resolved all issues between the two states.

On 1 May 2014, China towed an oil rig into disputed territory in the South China Sea. This action reignited the conflict between the two countries. Naval clashes around the oil rig resulted in casualties of sailors and damaged ships. The Vietnamese people erupted in protest. The Vietnamese government allowed, and even encouraged, massive demonstrations that turned violent resulting in the destruction of Chinese businesses and multiple casualties. The protests resulted in the death of two Chinese Nationals and one hundred injured, and caused the Chinese government to launch an immediate evacuation of its citizens living in Vietnam. ${ }^{2}$ The protests surprised the Chinese and threatened the internal stability of Vietnam.

${ }^{1}$ Xiaoming Zhang, "China's 1979 War with Vietnam: A Reassessment," The China Quarterly 184, no. -1 (December 2005): 851, accessed July 10, 2014, http://dx.doi.org/10.1017/S0305741005000536.

${ }^{2}$ Hilary Whitman, "How an oil rig sparked anti-China riots in Vietnam," Cable News Network, May 19, 2014, Accessed July 10, 2014, http://www.cnn.com/2014/05/19/world/asia/china-vietnam-islands-oil-rigexplainer/index.html?iref=allsearch. 
The conflict in the South China Sea continues, causing new alliances and old foes to continue seeking strategic advantage. Territorial disputes remain, but these disputes were not paramount in 1979 and are questionably important today. The greater strategic context including the role of the Soviet Union and threatening alliances in the region resulted in the Chinese use of force in the past and provides insight for the future. This study examines the Sino-Vietnamese War through the lens of operational art to determine how China achieves their strategic objectives.

The problem identified for this study has four components. First, a potential conflict with China is a concern of American foreign policy. Second, most of the discussion over the potential conflict between the US and China focuses on US responses under the emerging Air Sea Battle doctrine and stops before the introduction of ground forces. The third component is the lack of knowledge about contemporary land operations by the People’s Liberation Army. Few examples are available to study and none since the Sino-Vietnamese War. Additionally, most of the collective knowledge on Chinese ground forces is from the Korean Conflict from 1950 to 1953, thirty years prior to the Sino-Vietnamese War and under a different Chinese domestic regime. Finally, military planners have a responsibility to study potential opponents, "He who knows the enemy and himself will never in a hundred battles be at risk.”3 Thus, this study contends that the Chinese conducted operational art by arranging tactical actions to achieve their strategic objectives in the Sino-Vietnamese War.

The purpose of this study is to examine the last land campaign conducted by the People's Liberation Army (PLA) and the People's Army of Vietnam (PAVN) to examine how both forces achieved their strategic objectives. The study will increase the level of understanding of the PLA, the PAVN, and the sources of instability in the region. The study uses the viewpoint of both

${ }^{3}$ Sunzi, Sun-tzu: The Art of Warfare, Classics of Ancient China (New York: Ballantine Books, 1993), 113. 
China and Vietnam to gain a full understanding of the War but could not conclude decisively on Vietnam's use of operational art due to limited resources. The focus on ground forces will complement research into Air Sea Battle in the Pacific. The study provides a model for future operational planners to consider when planning for contingencies in the Pacific Theater.

This study is significant for strategic and operational planners to understand how the Chinese and Vietnam fight land campaigns. The strategic rebalance to the Asia-Pacific Theater increases the region's relevance to American planners. In addition, recent events increase the usefulness of studying past conflicts between the actors in the region and sources of conflict. Since the Sino-Vietnamese War is the last time China committed ground forces, the case provides insight into China's threshold to use force and the decision making process employed. The study also provides insights into the future Chinese and Vietnamese use of force.

The theoretical framework for this study is operational art. US Army doctrine defines operational art as "the pursuit of strategic objectives, in whole or in part, through the arrangement of tactical actions in time, space, and purpose.”4 Joint Department of Defense doctrine defines operational art as "the cognitive approach by commanders and staffs, supported by their skill, knowledge, experience, creativity, and judgment, to develop strategies, campaigns, and operations to organize and employ military forces by integrating ends, ways, and means.” 5 Operational art is also defined as the "planning, execution and sustainment of temporally and spatially distributed maneuvers and battles, all viewed as one organic whole.”6

${ }^{4}$ Army Doctrine Publication (ADP) 3-0, Unified Land Operations, (Washington, DC: Government Printing Office, 2011), 9.

${ }^{5}$ Joint Publication (JP) 1-02, Department of Defense Dictionary of Military and Associated Terms, (Washington, DC: Government Printing Office, 2012), 194.

${ }^{6}$ James J Schneider, Vulcan's Anvil: The American Civil War and the Foundations of Operational Art (Fort Leavenworth: Presidio Press, 1994), 28. 
Operational art consists of multiple elements including four used for this study: tempo, operational reach, depth, and simultaneity. The first term is tempo. US Army doctrine defines tempo as the "relative speed and rhythm of military operations over time with respect to the enemy." 7 Another definition for tempo is the "frequency or pace at which things happen." ${ }^{8}$ The second term is operational reach. US Army doctrine defines operational reach as the "distance and duration across which a joint force can successfully employ military capabilities." ${ }^{9}$ The third term is depth. US Army doctrine defines depth as the "extension of operations in space, time, and purpose." ${ }^{10}$ The concept of depth is also the cognitive linking of operational aim, subsequent missions, and immediate missions. ${ }^{11}$ The last term is simultaneity defined as "existing, occurring, or operating at the same time.” ${ }^{2}$ Robert Leonhard provides a definition of simultaneity through a military viewpoint as "several decisive events occurring at once."13

Four hypotheses test the thesis for the study within the theoretical framework of operational art. The first hypothesis is when China and Vietnam achieve tempo they achieve their strategic objectives. The second hypothesis is when China and Vietnam achieve depth they achieve their strategic objectives. The third hypothesis is when China and Vietnam achieve

${ }^{7}$ Army Doctrine Reference Publication (ADRP) 3-0, Unified Land Operations, (Washington, DC: Government Printing Office, 2012), 4-7.

${ }^{8}$ Robert R. Leonhard, Fighting by Minutes: Time and the Art of War (Westport, CT: Praeger, 1994), 7.

${ }^{9}$ ADRP 3-0, 4-5.

${ }^{10}$ ADP 3-0, 8.

${ }^{11}$ Shimon Naveh, The Cummings Center Series, vol. 7, In Pursuit of Military Excellence: the Evolution of Operational Theory (London: Frank Cass, 1997), 233.

12 Dictionary.com, “Simultaneity,” accessed 23 February 2014, http://dictionary.reference.com/browse/simultaneity.

${ }^{13}$ Leonhard, Fighting by Minutes: Time and the Art of War, 91. 
operational reach they achieve their strategic objectives. The fourth hypothesis is when China and Vietnam achieve simultaneity they achieve their strategic objectives. The nature of the SinoVietnamese War, the criticism of Chinese actions, and their relation to each other determined the hypotheses. The study has six research questions that guide the collection of empirical evidence. The research questions relate to the hypotheses within the operational art theoretical framework. The first question is what were the strategic objectives of China and Vietnam? The second question is what were the strategic approaches of China and Vietnam? The third question is how did China and Vietnam achieve tempo? The fourth question is how did China and Vietnam achieve depth? The fifth question is how did China and Vietnam achieve operational reach? The last question is how did China and Vietnam achieve simultaneity?

This study is limited to secondary sources that compile and translate primary sources from China and Vietnam. The study is also reliant on US Government open source documents. The time examined in this study is from the beginning of defensive preparations in July 1978 to the beginning of negotiations in May 1979. The study will primarily focus on the land forces of China and Vietnam.

This study assumes that the United States will continue to have an interest in Chinese and Vietnamese military capabilities and their effects on US policy in the region. The PLA has undergone several modernization efforts in the last thirty years. This requires the assumption that improvements in tactical abilities do not fundamentally change how the PLA will arrange tactical actions to achieve strategic objectives. Thus, the insights from the Sino-Vietnamese conflict are a valid starting point for understanding how China uses military force.

Following this introduction, this monograph contains five additional sections. The next section is a literature review. The third section is the methodology used to conduct the study. The fourth section contains the case study of the Sino-Vietnamese War. The fifth section contains the finding and analysis of the study. The final section concludes the study. 


\section{Literature Review}

This section presents the rationale for conducting research on China and Vietnam's use of operational art during the Sino-Vietnamese War to achieve their strategic objectives. The literature review focuses on the Chinese use of military force because material on Vietnam's use of military force is limited. Chinese literature exists in great depth. Much of the research conducted on Chinese operational art focuses on: the Chinese way of war; its roots in Sun-Tzu's Art of Warfare and Tao; and the principles of deception, strategic advantage, strategic positioning, and shaping defined in the Art of Warfare. Multiple studies have shown how Chinese wars have followed the Sun-Tzu adage to "only enter battle after first won the victory." ${ }^{14}$ Other studies have looked at the Chinese application of the principles of war. Studies on the Korean Conflict fully documented the Chinese use of surprise and mass. However, the focus on principles of war underestimates Chinese skill at arranging tactical actions to achieve strategic objectives. Therefore, this research will look at four elements of operational art for a deeper understanding of the Chinese way of war.

The elements of operational art used in this study are key to the paper's relevance in the future. The Chinese doctrine, training, organization and material modernization program that began after the Sino-Vietnamese War likely changed the tactics of the Chinese. This study does not focus on specific Chinese or Vietnamese tactics, but at how the tactics link to the achievement of ends. Tempo, operational reach, depth and simultaneity were key elements to operational art in the Sino-Vietnamese War. The following review of the literature represents the research applicable to this study organized into three sections: Chinese Operational Art; the SinoVietnamese War strategy; and Chinese operational effectiveness in the Sino-Vietnamese War.

\footnotetext{
${ }^{14}$ Sunzi, Sun-tzu: The Art of Warfare, 116.
} 


\section{Theoretical Framework}

The theoretical framework for this study is operational art. US Army doctrine defines operational art as "the pursuit of strategic objectives, in whole or in part, through the arrangement of tactical actions in time, space, and purpose." ${ }^{15}$ US joint doctrine defines operational art as "the cognitive approach by commanders and staffs, supported by their skill, knowledge, experience, creativity, and judgment, to develop strategies, campaigns, and operations to organize and employ military forces by integrating ends, ways, and means.” ${ }^{16}$ The joint doctrine expands the scope of the theoretical framework and allows for greater application outside US military operations. The purpose for using operational art as the theoretical framework is not to apply American definitions and the American way of war to the Chinese. This study does not "cut the feet to fit the shoes” as Mao warns against. ${ }^{17}$ This paper uses this framework, whose theoretical basis and language is familiar to US operational planners, to review Chinese and Vietnamese strategic aims and the tactics of their land forces.

Soviet theorists developed the term operational art. Georgii Samoilovich lsserson’s 1937 paper "The Evolution of Operational Art” is an excellent source to explain the theory starting with its origins. ${ }^{18}$ Isserson defined operational art as a "series of uninterrupted operational efforts that merge into a single whole.” ${ }^{19}$ Operational art is not a checklist, but "presupposes freedom of

${ }^{15}$ ADP 3-0, 9.

${ }^{16}$ JP 1-02, 194.

${ }^{17}$ Mao Tse-Tung, Selected Military Writings of Mao Tse-Tung (Peking: Foreign Languages Press, 1972), 78.

${ }^{18}$ Schneider, Vulcan's Anvil, 20.

${ }^{19}$ G S. Isserson, The Evolution of Operational Art, 2nd ed., trans. Bruce Menning (Fort Leavenworth, KS: Combat Studies Institute Press, US Army Combined Arms Center, 2013), 48. 
methods and forms...carefully chosen to fit a concrete situation.” ${ }^{20}$ Isserson argued that military leaders require operational art to achieve any strategic objective with large troop formations.

In his paper "Vulcan’s Anvil: The American Civil War and the Foundations of Operational Art,” James J. Schneider characterizes operational art as the "employment of forces in deep distributed operations." ${ }^{21}$ Operational art is the "planning, execution and sustainment of temporally and spatially distributed maneuvers and battles, all viewed as one organic whole.”22 Operational art may require operational maneuver to "maximize the flow of force in tempo and density.” ${ }^{23}$ The intent of operational maneuver is to maximize freedom of action to destroy an enemy’s capacity to wage war. ${ }^{24}$

The operational art theoretical framework is consistent with Eastern military theories. Sun-tzu and Mao Tse-tung did not use the term operational art, but the connection and interdependence between strategic aims and tactical actions were central to their theories. For example, Mao emphasized the link between strategy and tactics, "an understanding of the whole facilitates the handling of the part, and because the part is subordinate to the whole. The view that strategic victory is determined by tactical success alone is wrong because it overlooks...whether the situation as a whole and its various stages are taken into account.” ${ }^{25}$ In addition, Mao explained that one principle of military operations was to "center our attention on the important

${ }^{20}$ Ibid., vii.

${ }^{21}$ Schneider, Vulcan's Anvil, 28.

${ }^{22}$ Ibid.

${ }^{23}$ Ibid., 31

${ }^{24}$ Ibid.

${ }^{25}$ Mao Tse-Tung, Selected Military Writings of Mao Tse-Tung, 81-82. 
links that have a bearing on the whole.” ${ }^{26}$ The theoretical framework for the study is relevant to current military doctrine and past military theories from Isserson to Mao. Four concepts within the theoretical framework are central to this study.

\section{Key Concepts}

The key concepts for this research are four relevant elements of a generalized operational art framework: tempo, depth, operational reach and simultaneity. The first key concept is tempo. Tempo is an important component of operational maneuver as defined in Schneider's operational art theory with the purpose of creating freedom of action by dictating the pace of operations to the enemy. US Army doctrine defines tempo as the "relative speed and rhythm of military operations over time with respect to the enemy." ${ }^{27}$ An alternative definition to tempo is the "frequency or pace at which things happen.” 28 Tempo is evaluated by its pace and relative speed with respect to the enemy, but also the strategic situation as a whole. Sun-tzu wrote on the importance of the pace of operations in reference to time and strategy, “in joining battle, seek the quick victory. If battle is protracted, your weapons will be blunted and your troops demoralized.”29

The next key concept is depth. In Isserson's theory of operational art, the purpose of depth was to shock an adversary's system to cause collapse with minimal damage to the system components. ${ }^{30}$ US Army doctrine defines depth as the "extension of operations in space, time,

${ }^{26}$ Ibid., 83.

${ }^{27}$ ADRP 3-0, 4-7.

${ }^{28}$ Leonhard, Fighting by Minutes: Time and the Art of War, 7.

${ }^{29}$ Sunzi, Sun-tzu: The Art of Warfare, 107.

${ }^{30}$ Isserson, The Evolution of Operational Art, vii. 
and purpose.”31 Importantly, the concept of depth is also cognitive. Shimon Naveh defined depth as the cognitive linking of operational aim, subsequent missions, and immediate missions. ${ }^{32}$ Naveh’s definition is more appropriate to an Eastern approach to warfare. Mao defined the concept of depth in his considerations for strategy, "give proper consideration to the relation between various campaigns or between various operational stages” and "proper consideration to the relation between the front and rear.”33

Operational reach is the next key concept and relates to depth. The purpose of operational reach is to maintain the initiative until an operation meets its objectives. US Army doctrine defines operational reach as the "distance and duration across which a joint force can successfully employ military capabilities.” ${ }^{34}$ Operational reach is also applicable to Eastern military thought. To maintain the initiative, Sun-tzu wrote that an expert in battle conscripted only the number of soldiers he could sustain, carried provisions with him, and fed his army from enemy soil. ${ }^{35}$

The last term is simultaneity defined as "existing, occurring, or operating at the same time.”36 Robert Leonhard provides a definition of simultaneity through a military viewpoint as “several decisive events occurring at once.” ${ }^{37}$ The concept of simultaneity was key to Schneider’s theory on operational art. Operations would not succeed if all forces massed on a single point, but

\footnotetext{
${ }^{31}$ ADP 3-0, 8.

${ }^{32}$ Naveh, In Pursuit of Military Excellence: the Evolution of Operational Theory, 233.

${ }^{33}$ Mao Tse-Tung, Selected Military Writings of Mao Tse-Tung, 83-84.

${ }^{34}$ ADRP 3-0, 4-5.

${ }^{35}$ Sunzi, Sun-tzu: The Art of Warfare, 108.

${ }^{36}$ Dictionary.com, accessed 23 February 2014.

${ }^{37}$ Leonhard, Fighting by Minutes: Time and the Art of War, 91.
} 
required distribution. ${ }^{38}$ Distributed operations are "extended in space and time but unified by a common aim.”39

\section{Empirical Research}

Three primary categories define the existing research on Chinese operational art and the Sino-Vietnamese War: Chinese Operational Art; the Sino-Vietnamese War strategy; and Chinese operational effectiveness in the Sino-Vietnamese War.

\section{Chinese Operational Art}

Past research on Chinese operational art or the Chinese way of war examined the topic from the two main perspectives of Chinese culture and Chinese world-view. Chinese cultural research referenced the role of Confucianism and Taoism on Chinese military theorists such as Sun-tzu and Mao Tse-tung. Cultural context is critical to understand Chinese strategic objectives. In their book The Philosophy of Chinese Military Culture, William H. Mott IV and Jae Chang Kim linked the ancient past philosophies to contemporary Chinese strategic culture. The Chinese culture "shaped and limited strategic choices and profoundly influenced China’s interactions with other states.”40 Mott and Kim explain that Euro-American cultures misunderstood these interactions and viewed them as irrational. ${ }^{41}$ Shih and Li are two cultural concepts that are important to comprehend the Chinese way of war. Shih and Li are strategies, Shih an indirect strategy and Li direct.

\footnotetext{
${ }^{38}$ Schneider, Vulcan's Anvil, 21.

${ }^{39}$ Ibid., 35.

${ }^{40}$ William H. Mott and Jae Chang Kim, The Philosophy of Chinese Military Culture:
} Shih Vs. Li (New York, N.Y.: Palgrave Macmillan, 2006), 6.

${ }^{41}$ Ibid., 1. 
Shih (pronounced "sure"), ${ }^{42}$ in the context of military strategy is defined as power, force, or influence. ${ }^{43}$ Another author defined Shih as strategic advantage. ${ }^{44}$ Shih represented a "dynamic power and integrated force that combines the effects of material things, natural forces, and human factors in some action.” ${ }^{45}$ Shih also refers to the political ends for military means. When the Chinese utilized a Shih strategy, they would avoid a direct approach, and attack a strategy, to seek a political advantage. ${ }^{46}$

The Chinese use a Li, or "self-seeking” strategy by itself or inside a greater Shih strategy. ${ }^{47} \mathrm{Li}$ also refers to personal advantage, benefit, or tangible interests. ${ }^{48} \mathrm{~A}$ Li strategy is consistent with a Jominian decisive point strategy focused on enemy destruction through overwhelming force. Mott and Kim argued the Chinese military culture preferred a Shih strategy that viewed the use of force broadly through space and time. ${ }^{49}$ Mott and Kim's study provided a theoretical framework to understand Chinese motivations through the Chinese culture and its roots in Confucianism and Taoism.

In his book Modern Chinese Warfare, Bruce Elleman links the Chinese worldview to the Chinese way of war. His argument provides a different lens to understand Chinese strategic objectives. The PLA arranges tactical actions based on the relation of strategic objectives, only

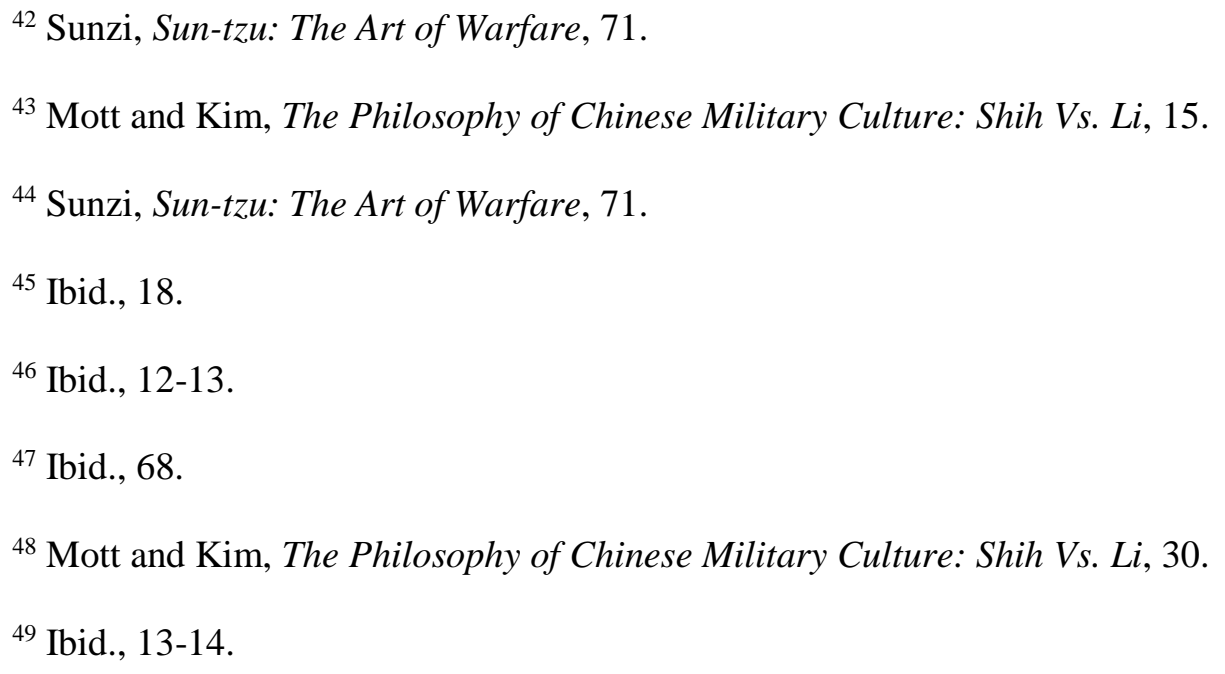


fully comprehended when understanding the Chinese worldview. He suggests the purpose of the Chinese military is to create or preserve the unity of China. In the case of the Sino-Vietnamese War and other limited wars in the latter half of the $20^{\text {th }}$ Century, Elleman argues that China's goal was to unify its colonies and tributaries. ${ }^{50}$ China saw French Indochina, defined as the countries of Vietnam, Laos, and Cambodia, as tributaries to China. These countries owed China for its support during fighting with Western powers. Any other country trying to influence this region affected Chinese Shih.

\section{Sino-Vietnamese War Strategy}

The majority of research on the Sino-Vietnamese War examined the strategic environment and strategic objectives of China and Vietnam. This research focused on why the war occurred and what it achieved. How China shaped the strategic environment through a series of internal, regional, and international steps prior to its attack provides insights into China’s purpose. In their book The Third Indochina War, Odd Arne Westad and Sophie Quinn-Judge identified the four causes of the war as: China’s world-view; Chinese view of French Indochina; Vietnam's attack into Cambodia in December of 1978; and the Vietnamese treatment of Chinese in Vietnam. ${ }^{51}$ Soviet intentions to influence Vietnam and the United States recognition of China shaped the strategic environment. ${ }^{52}$ In his book China's War with Vietnam, 1979, King C. Chen examined the multiple deliberate political steps China took prior to the commitment of ground

${ }^{50}$ Bruce A. Elleman, Modern Chinese Warfare, 1795-1989, Warfare and History (London: Routledge, 2001), xii.

${ }^{51}$ Odd Arne Westad and Sophie Quinn-Judge, eds., Cold War History, vol. 11, The Third Indochina War: Conflict between China, Vietnam and Cambodia, 1972-79 (New York: Routledge, 2006), 4.

${ }^{52}$ King C. Chen, China's War with Vietnam, 1979: Issues, Decisions, and Implications (Stanford, Calif.: Hoover Institution Press, Stanford University, 1987), 82. The United States officially recognized the People's Republic of China on 15 December 1978 and established diplomatic ties 01 January 1979. 
forces. These steps included diplomatic actions with the Soviet Union and the United States and internal political actions taken by Deng Xiaoping, one of the Chinese Vice Premier’s. ${ }^{53}$

\section{Chinese Operational Effectiveness}

The final category of research conducted into the Sino-Vietnamese War is a study by Edward C. O’Dowd titled Chinese Military Strategy in the Third Indochina War. This study examined the effectiveness of Chinese forces during the war and concluded that the PLA were ineffective since they failed to achieve the strategic goal of forcing the Vietnamese to abandon Cambodia. ${ }^{54}$ O’Dowd examined military effectiveness based on three factors: military unit’s ability to achieve their assigned task; time it took to achieve the task; and the number of troops required to achieve the task. ${ }^{55}$ This research does attempt to tie tactical actions to the achievement of strategic goals, but the framework does not give an understanding for China's future application of force.

A clear gap exists in the current research on the Chinese and Vietnamese land campaign during the Sino-Vietnamese War. Therefore, this research is important to examine how the PLA and PAVN conducted operational art to achieve strategic objectives. The study uses four hypotheses to test the study's thesis. The first hypothesis is when China and Vietnam achieve tempo they achieve their strategic objectives. This hypothesis will test the overall pace and relative speed of one force with respect to the other. The next hypothesis is when China and Vietnam achieve depth they achieve their strategic objectives. This hypothesis will examine if the PLA and PAVN linked operations through depth to overwhelm their adversary. The third

${ }^{53}$ Chen, China's War with Vietnam, 1979, 84.

${ }^{54}$ Edward C. O'Dowd, Chinese Military Strategy in the Third Indochina War: The Last Maoist War, Asian Security Studies (London: Routledge, 2007), 4. Vietnamese ground forces did not leave Cambodia until 1989.

${ }^{55}$ Ibid., 7. 
hypothesis is when China and Vietnam achieve operational reach they achieve their strategic objectives. This hypothesis will examine if the PLA and PAVN possessed the operational reach to maintain the initiative and operations until achieving their strategic objectives. The last hypothesis is when China and Vietnam achieve simultaneity they achieve their strategic objectives. This hypothesis will determine if the PLA or PAVN distributed their forces in space and purpose with the same aim to achieve their objectives.

This section presented the rationale for conducting research on China's use of operational art during the Sino-Vietnamese War to achieve their strategic objectives. The section discussed and generalized the theoretical framework of operational art from its theoretical roots to apply to the Chinese context. This section also defined the key concepts to focus the relevant elements of operational art. Empirical research consists of three sections: Chinese Operational Art, the SinoVietnamese War strategy, and Chinese operational effectiveness in the Sino-Vietnamese War. The study’s thesis fills a gap in existing research. Finally, the four hypotheses were justified for testing the thesis. The next section will discuss the methodology used for the research. 


\section{Methodology}

The primary goal of this study was to test the research questions related to the use of operational art by China. This section presents the methodology employed to test the research question. This section consists of three parts: the selection of the case study, method of analysis, and data collection.

This section describes the selection of the Sino-Vietnamese War as the case study most relevant to examining the Chinese and Vietnamese use of operational art. The use of a single case study allows for valid generalizations of operational art for application to future scenarios. The selection of the Sino-Vietnamese War is important for three main reasons. First, the SinoVietnamese War was the last land campaign conducted by the PLA and PAVN. After this war, the PLA began a series of modernization efforts probably inspired from internal lessons learned of the war. The tactics and equipment used in the Sino-Vietnamese War will likely not be the same in future ground campaigns, but the operational art the PLA used to link tactics to achieve strategic aims will be relevant. Second, ground forces fought the war with little action by the naval or air forces. This allows for a detailed examination of how the PLA and PAVN fight relevant for future operational planners with a concern for ground forces. Finally, the Chinese had clear strategic objectives that are easier to determine than other wars because of the "cultural revolution" that occurred immediately prior to the campaign. The "cultural revolution” affected the release of information related to Chinese strategy allowing for a level of transparency not normally found in Chinese military studies.

The study will use the method of "structured, focused comparison" as defined in the book Case Studies and Theory Development by Alexander George and Andrew Bennett. The focus of the study is the Sino-Vietnamese War using the framework of operational art. This study examines four elements as variables inside the theoretical framework. The use of these elements, or variables, allows for further research into other operations and provides leverage points for 
future operational planners. The study uses structured research questions to examine the variables and to relate this study to others.

This study collected empirical evidence with six research questions in order to test the hypotheses. The six questions determine the validity of the hypotheses for both adversaries in the single case study of the Sino-Vietnamese War. The previously identified gap in existing research shaped the questions. In addition, the questions are necessary to use the theoretical framework of operational art.

The first research question is what were the strategic objectives of China and Vietnam? The strategic objectives were necessary to understand in order to determine what each side in the war wanted to achieve. Since operational art is the arrangement of tactical actions to achieve strategic objectives, this question is critical to the analysis. The researcher expected to find that the strategic objectives were clear to the Chinese and Vietnamese leaders, and that the strategic context shaped the objectives.

The second research question is what were the strategic approaches of China and Vietnam? This question looked at how the Chinese and Vietnamese Commanders visualized the arrangement of operations to achieve the strategic objectives. The researcher expected to find a clear visualization that led to the plans for the war. Since the war had limited objectives conducted inside a broader strategic context, the researcher expected to find approaches that balanced the interests of the actors.

The next four research questions involve the specific elements of operational art the researcher expected to find in the arrangement of tactical actions employed by the Chinese and Vietnamese. The third question is how did China and Vietnam achieve tempo? Since tempo is the relative speed of operations with respect to the enemy, the metric for this question was time as related to the operational and strategic environment. The researcher expected to find the attacker 
with the initiative maintained a deliberate tempo relative to the environment and the capabilities of the defender.

The fourth research question is how did China and Vietnam achieve depth? The study used two metrics to measure depth. The first was physical depth employed on the battlefield and looked at the operations across time and space. The second metric was temporal and evaluated the purpose and the effect of the operations on the adversary. The researcher expected to find a clear physical link between operations that resulted in temporal adversary effects.

The fifth research question is how did China and Vietnam achieve operational reach? This research question required multiple metrics. The first two metrics were the distance and time required to sustain operations. The third metric evaluated if China and Vietnam sustained operations over the distance and time required to achieve strategic objectives. The researcher expected to find that China and Vietnam possessed the operational reach to achieve their objectives.

The last research question is how did China and Vietnam achieve simultaneity? The metric for this research question was the number of distributed operations occurring at the same time for the same purpose. The only operations considered were those that were not mutually supporting with direct or indirect fires. The researcher expected to find that both China and Vietnam achieved simultaneity.

This section discussed the selection of the case study, the method of analysis, and the data collection conducted during research. The methodology was valid based on the metrics used for data collection. The next section presents the Sino-Vietnamese War case study. 


\section{The Sino-Vietnamese War}

This study uses the Sino-Vietnamese War fought from 17 February 1979 to 16 March 1979 as a case study to test the operational art hypotheses. This section provides an overview of the Sino-Vietnamese War, answers the research questions necessary to test the hypotheses, and provides an assessment of these answers. The case is examined beginning with the strategic objectives and approach of China and Vietnam and the tactical actions arranged to achieve them through the use of tempo, operational reach, depth, and simultaneity.

The Sino-Vietnamese War is relevant to the examination of Chinese and Vietnamese operational art because the strategic objectives for the two forces are identifiable and it is the last land campaign conducted by China. The Chinese Cultural Revolution that preceded the campaign and the recent release of relevant Chinese diplomatic relations with the United States allow for greater understanding of the strategic objectives. Both land component commanders were constrained to keep the war limited to the region and to Chinese and Vietnamese ground forces. The limited objectives of the War allow for a deeper understanding of the operational art employed by the adversaries. Although the war had limited objectives, it was still a significant campaign with multiple divisions engaged in combined arms operations in three distinct sectors. Finally, the capabilities of the People’s Liberation Army and the People’s Army of Vietnam’s ground forces were similar and this parity required the use of operational art to achieve objectives.

In April 1975, two communist regimes took power and reshaped the strategic environment of Asia. The Khmer Rouge gained control of Cambodia on 17 April followed by North Vietnam reuniting Vietnam on the $30^{\text {th }}$. These two communist countries previously supported each other and the Chinese aided both during the Second Indochina War. However, after achieving their objectives in 1975, the consolidation of internal power took precedence over past support. For the new Socialist Republic of Vietnam, an appeal to their historical hegemony 
in Indochina, became a rallying cry to unite a country fractured by civil war. ${ }^{56}$ In December 1975, Vietnam aided a government overthrow in Laos and permanently garrisoned soldiers there to protect Vietnamese interests. In December 1978, Vietnam invaded Cambodia to replace the Khmer Rouge regime of Pol Pot with one amicable to Vietnamese regional hegemony. Also in 1978, the Soviet Union and Vietnam signed the “Treaty of Friendship and Cooperation” to counter Chinese influence and guarantee military and economic support for rebuilding Vietnam. ${ }^{57}$ Under this treaty, the Soviet Union provided military support, $\$ 700$ million in $1978,{ }^{58}$ for operations in Laos and Cambodia. The Vietnam-Soviet treaty went into effect prior to Vietnam's invasion of Cambodia and replaced a similar Sino-Soviet treaty that had expired on 14 February $1979 .{ }^{59}$ In this strategic environment, China was losing influence in the region to its historical "little brother" of Vietnam. China had to act to reassert its Shih in the region. ${ }^{60}$ This study provides an overview of the Sino-Vietnamese War by examining the terrain, the Vietnamese defense plan, the Chinese attack plan and the subsequent actions by both countries.

The terrain from Hanoi north into China affected the plans of both the PAVN and PLA (see Figure 1). Hydrology, mountains and vegetation defined the avenues of approach to Hanoi from the north. To the west of Hanoi, the Black, Red and Clear River result in few major roads from Hanoi to the Chinese border. These rivers also limit cross mobility corridor movement. The terrain is more mountainous to the northwest of Hanoi and includes the tallest mountain in

${ }^{56}$ Westad and Quinn-Judge, The Third Indochina War, 214.

${ }^{57}$ Charles McGregor, The Sino-Vietnamese Relationship and the Soviet Union. Adelphi Papers 232 (London: The International Institute for Strategic Studies, 1988), 91-94.

58 Thu-Huong Nguyen-Vo, Khmer-Viet Relations and the Third Indochina Conflict (Jefferson, N.C.: McFarland, 1992), 124.

${ }^{59}$ Chen, China's War with Vietnam, 1979, 93.

${ }^{60}$ Mott and Kim, The Philosophy of Chinese Military Culture: Shih Vs. Li, 15. 
Vietnam, Fan Xi Pan at over 3,000 meters. The dense vegetation in the northwest also affects movement off roads. To the east of the Clear River, the elevation flattens and the vegetation is less dense. In addition, a depression runs from Cao Bang through Lang Son to the South China Sea that increases the number of mobility corridors and allows for greater cross mobility corridor movement. Three major avenues of approach exist from the Chinese border to Hanoi. The farthest west avenue of approach follows the Red River and is 295 kilometers to Hanoi. In the center, the avenue of approach from Cao Bang to Hanoi is 276 kilometers, and meets with the east avenue of approach north of Hanoi and the Red River. The eastern avenue of approach is the shortest at 154 kilometers and is the historical invasion route from China into Vietnam. ${ }^{61}$ The terrain similarly affected the PLA ability to sustain the attack from Chinese territory. Roads and railways in China from the major cities of Nanning and Guangzhou easily supplied the Cao Bang and Lang Son avenues of approach. Movement to the Lao Cai avenue of approach is more difficult and requires following an indirect route from Guangxi to Yunnan Province.

${ }^{61}$ O'Dowd, Chinese Military Strategy in the Third Indochina War, 49. Chinese forces attacked through the Lang Son avenue of approach in 1077, 1288 and 1427. 


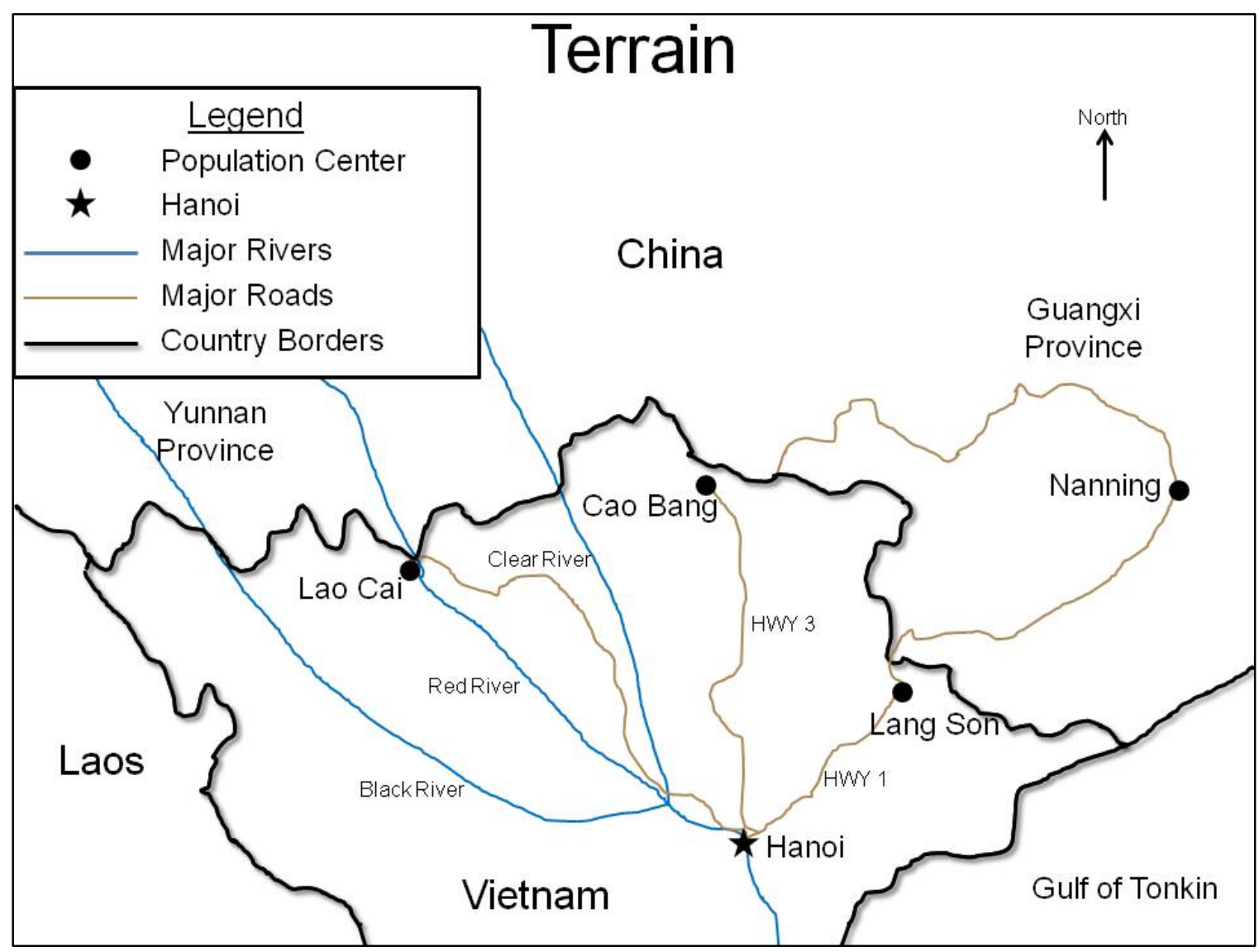

Figure 1. Terrain of Northern Vietnam

Source: Drawing adapted from data in Eleanor Jane Sterling, Martha Maud Hurley, and Le Duc Minh, Vietnam: a Natural History (New Haven: Yale University Press, 2006), 157-163.

Vietnam's military objective was to retain Hanoi. The PAVN established an area defense to accomplish this objective (see Figure 2). In 1979, the PAVN consisted of 600,000 soldiers. Two hundred thousand soldiers were conducting operations in Cambodia against the Khmer Rouge, and 100,000 were securing Vietnamese interests in Laos leaving 300,000 soldiers for the defense of Vietnam. The deep, close, support operational framework best describes the PAVN defense. The support area was Hanoi. The PAVN established three non-contiguous close areas on the three main avenues of approach from China to Hanoi consisting of five total divisions. In the deep area, militia forces conducted security operations forward to the border. From west to east, 
two divisions defended Lao Cai tasked to delay PLA forces along the western avenue of approach along the Red River. The PAVN emplaced these two divisions in December 1978 and had two months to prepare their defenses. ${ }^{62}$ Two divisions defended Cao Bang tasked to delay PLA forces along the center avenue of approach. The PAVN emplaced these forces in early February 1979 and afforded them the least amount of time to prepare. ${ }^{63}$ The famed PAVN $3^{\text {rd }}$ Division defended the eastern avenue of approach centered in Lang Son. The Third Division formed during the Second Indochina War to fight in South Vietnam against US forces. The Division then led the attack to seize Saigon in $1975 .{ }^{64}$ The PAVN weighted the Third Division with tanks, an artillery regiment and air defense regiment, all tasked to delay the PLA along the most likely and fastest avenue of approach to Hanoi. The Third Division prepared their defense over seven months. The primary Vietnamese course of action was for the militia forces to provide early warning and disrupt the PLA attack as it crossed the border. The main battle area divisions would then delay the PLA attack and retrograde to subsequent battle positions along their avenues of approach until reaching final positions centered on Hanoi.

\footnotetext{
${ }^{62}$ O'Dowd, Chinese Military Strategy in the Third Indochina War, 70.

${ }^{63}$ Ibid., 50.

${ }^{64}$ Ibid., 76.
} 


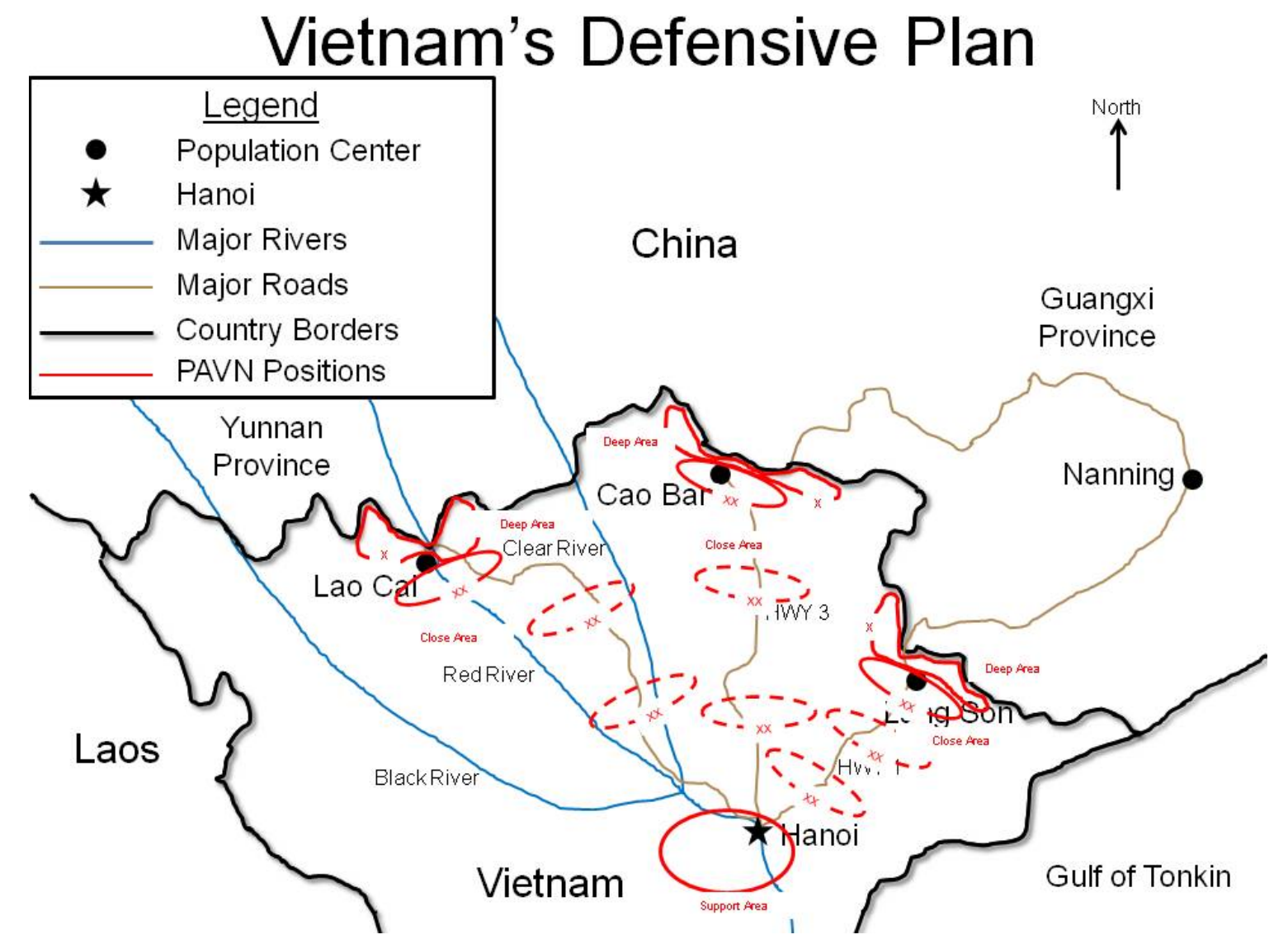

Figure 2. Vietnam's Defensive Plan

Source: Drawing adapted from data in Edward C. O'Dowd, Chinese Military Strategy in the Third Indochina War: The Last Maoist War, Asian Security Studies (London: Routledge, 2007), 45-52.

The military objective for the PLA was to defeat the forward PAVN divisions and seize the decisive terrain of Lang Son. The PLA employed 330,000 soldiers, task organized into eleven armies to achieve this objective. ${ }^{65}$ The PLA divided their attack along the three avenues of approach to Hanoi (see Figure 3). From west to east, three armies conducted a supporting attack along the western avenue of approach to defeat the PAVN defense and seize Lao Cai. The main effort with five armies attacked to defeat the PAVN defense, seize Cao Bang and isolate Lang

${ }^{65}$ Chen, China's War with Vietnam, 1979, 102. 
Son along the center avenue of approach. The east supporting effort with three armies attacked on the eastern avenue of approach to seize key terrain necessary to continue the attack on Lang Son. The plan for the attack consisted of three phases. The first phase required penetrating the PAVN deep area, the defeat of the PAVN defenses in the west and center, and the seizure of Lao Cai and Cao Bang. The PLA plan was to seize the decisive terrain of Lang Son in the second phase. The third phase was the withdrawal of all forces north of the border. The plan set a limit of advance fifty kilometers into Vietnam for all ground forces.

\section{China's Offensive Plan}

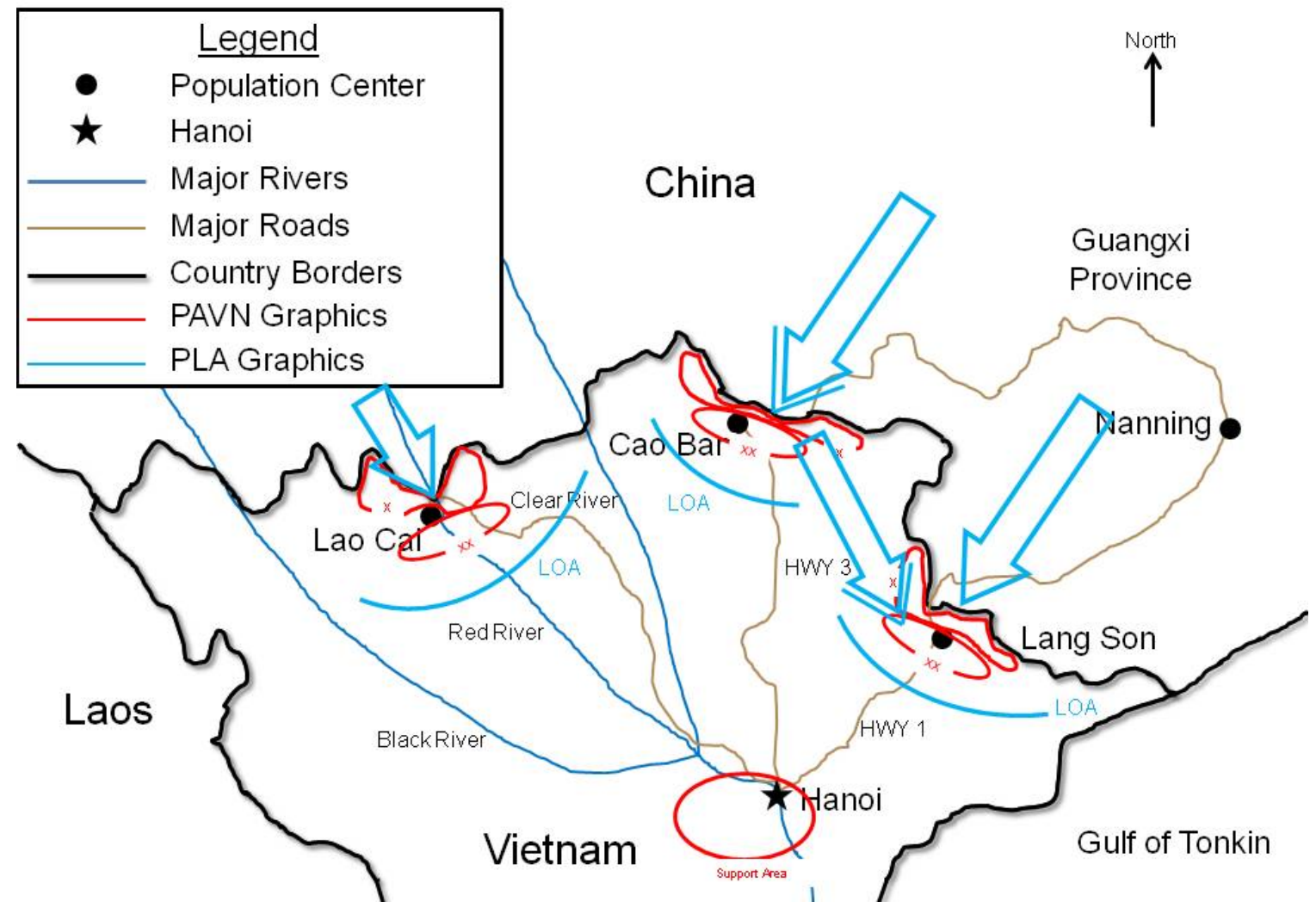

Figure 3. China’s Offensive Plan

Source: Drawing adapted from data in Edward C. O'Dowd, Chinese Military Strategy in the Third Indochina War: The Last Maoist War, Asian Security Studies (London: Routledge, 2007), 45-52.

The PLA attack began 17 February 1979. The PLA forces attacked simultaneously along 
all three avenues of approach. In the west, the PLA achieved its initial objective, the city of Lao Cai, by 19 February. The western PLA force then threatened further south by penetrating 40 kilometers by 1 March. In the center, the PLA destroyed the PAVN defenses and seized Cao Bang by 25 February. In the east, the PLA attacked across the border and seized key terrain around Lang Son, isolating the city from the north and south. The PLA achieved all first phase objectives by 25 February. On the $27^{\text {th }}$, the second phase began with the main effort attacking south to Lang Son. The PLA defeated the PAVN defense and seized the north side of Lang Son on 2 March. The PLA continued the attack until all of Lang Son was under Chinese control on 5 March. Within hours of seizing Lang Son, China announced their withdrawal and ended all attacks. ${ }^{66}$ The PLA completed the withdrawal to Chinese territory on 16 March ending the campaign. After the Chinese withdraw, the Vietnamese government agreed to negotiations that began in Hanoi in May 1979. ${ }^{67}$

\section{Research Questions}

The first question is what were the strategic objectives of China and Vietnam during the Sino-Vietnamese War? For China, the aim was to eliminate external vulnerabilities and to consolidate internal power around Deng Xiaoping, one of China's fourteen Vice Premier's. ${ }^{68}$ China had two strategic objectives in order to eliminate external vulnerabilities. First, China wanted to discredit the Soviet Union's support of Vietnam recently guaranteed in a treaty. This treaty unified two countries sharing large borders with China and threatened to upset the balance of power in the region. Second, China wanted to deny Vietnamese attempts to establish regional

${ }^{66}$ Zhang, "China's 1979 War with Vietnam,” 865.

${ }^{67}$ David Paul Nickles, Foreign Relations of the United States, 1977-1980, Volume XIII, China (Washington: United States Government Printing Office, 2013), 838.

${ }^{68}$ Nickles, Foreign Relations of the United States, 818. Trip report from Treasury Secretary Michael Blumenthal to President Jimmy Carter submitted March 5, 1979. 
hegemony by diverting pressure from operations in Cambodia. ${ }^{69}$ The Chinese supported the recently deposed Khmer Rouge government in Cambodia led by Pol Pot. This force was still fighting Vietnamese forces on the border with Thailand. The Chinese objective was to pressure Vietnamese forces to abandon this fight to defend Vietnam. China messaged other strategic objectives for the war including: cessation of Vietnam's incursions into China; normalizing border relations; and protecting ethnic Chinese in Vietnam. ${ }^{70}$

Vietnam's strategic objective was to dominate the Indochina region of Vietnam, Laos, and Cambodia and form an Indochina Federation. ${ }^{71}$ In Vietnam's view, Indochina, defined as Vietnam, Laos, and Cambodia, was within its historical sphere of influence because of cultural ties established as early as 850 BC. ${ }^{72}$ This regional influence was a source of Vietnamese pride and necessary to create a buffer from external threats. ${ }^{73}$ The worst-case scenario for Vietnam was a hostile threat to its north collaborating with a hostile threat to its west. Vietnam required Soviet support to generate the power it needed to dominate the Indochina region and balance power with a hostile China.

The second question is what strategic approaches did China and Vietnam use? The answer is China’s strategic approach was a limited offensive with ground forces to destroy Vietnamese defenses quickly to a depth that would threaten Hanoi. China’s approach had multiple influences and political leaders shaped the approach to ensure success prior to

${ }^{69}$ Zhang, "China's 1979 War with Vietnam,” 853.

${ }^{70}$ Steven J. Hood, Dragons Entangled: Indochina and the China-Vietnam War (Armonk, NY: M.E. Sharpe, 1992), 55.

${ }^{71}$ Nguyen-Vo, Khmer-Viet Relations and the Third Indochina Conflict, 134. Source defines the objectives, Henry Kissinger used the term Indochina Federation in his book On China.

${ }^{72}$ Ibid., 1-16.

${ }^{73}$ Ibid., 134. 
commencing military operations. General Xu Shiyou, the Commander of the PLA forces for the attack, described his approach as "niudao shaji (using a butcher’s knife to kill a chick)." "74 This approach relied on an overwhelmingly superior military force to destroy a weaker force at points of penetration. The approach was also recognizable as a limited offensive described by Carl Von Clausewitz in On War as a positive aim to reduce an adversary's natural resources and capture territory when full defeat of the enemy is not possible. ${ }^{75}$ This strategic approach also masterfully kept the war limited to ground operations between China and Vietnam. Deng Xiaoping shaped the strategic approach prior to combat operations in a three-step process clearly outlined by King C. Chen in his book China's War with Vietnam, $1979 .{ }^{76}$ Deng first consolidated political approval of the war internally. Next, China used diplomacy to ensure other countries in the region and the United States would not affect Chinese actions. Chinese leaders including Deng conducted multiple meetings with other countries to present the Chinese reasons for war with Vietnam. He traveled to the United States and met with US President Jimmy Carter 28 January to 05 February to gain support and ensure the war would not damage the improving U.S and Chinese relationship. ${ }^{77}$ The Chinese also met with the Soviet Union to ensure their support to Vietnam would be minimal. ${ }^{78}$ The PLA massed forces not required for the offensive into Vietnam on the

74Zhang, "China's 1979 War with Vietnam," 861.

${ }^{75}$ Carl von Clausewitz, On War, trans. Michael Howard, Peter Paret, and Bernard Brodie (Princeton, NJ: Princeton University Press, 1984), 611.

${ }^{76}$ Chen, China's War with Vietnam, 1979, 83.

${ }^{77}$ Chen, China's War with Vietnam, 1979, 91.

${ }^{78}$ Ibid., 110. 
Soviet Union border to defend against any Soviet response. ${ }^{79}$ China deployed Naval and Air Forces to deter, but not to achieve objectives themselves. The Chinese Navy deployed to defend against 15 ships of the Soviet Navy located off Vietnam's coast ${ }^{80}$ and to protect islands from Vietnamese attacks in the Paracel Archipelago. ${ }^{81}$ The Air Force supported with resupply missions and defended Chinese territory in case of an attack from the Vietnamese Air Force. ${ }^{82}$

Vietnam’s strategic approach was to defend Hanoi without disrupting operations in Cambodia or Laos. To preserve combat power, Vietnamese military leaders visualized an area defense to retain Hanoi. The PAVN approach relied heavily on 50,000 militia forces tasked to conduct security operations in the deep area. ${ }^{83}$

The third question is how did China and Vietnam achieve tempo? The answer is China did achieve a positive tempo with respect to the enemy in both the operational and strategic environment. Perceptions that China lacked tempo are consistent in research. However, none of the research examined historical rates of advance for operational maneuver in relation to the terrain located in Vietnam's northern region. The Chinese main effort attack on Cao Bang provides an example to analyze the relative speed of the PLA.

At Cao Bang, the PLA attacked with five armies against two PAVN divisions in a

${ }^{79}$ Harlan W. Jencks, “China's "Punitive” War on Vietnam: A Military Assessment,” Asian Survey 19, no. 8 (August 1979): 801-815, accessed July 10, 2014, http://dx.doi.org /10.1525/as.1979.19.issue-8, 808.

${ }^{80}$ Chen, China's War with Vietnam, 1979, 92.

${ }^{81}$ O'Dowd, Chinese Military Strategy in the Third Indochina War, 65.

${ }^{82}$ Ibid., 67.

${ }^{83}$ Jencks, "China's "Punitive” War on Vietnam” 808. Secondary sources vary in their estimates of total force numbers involved in the Sino-Vietnamese War. The study uses the estimation of the total Vietnamese force that defended as 50,000 militia and border troops and 50,000 regular PAVN Soldiers based on Jencks report soon after the war and O'Dowd's research published in 2007. Jencks estimated 300,000 PLA forces were committed for the campaign while O’Dowd estimated 472,000 PLA forces. 
fortified defense with trenches, tunnel systems, obstacles, and supporting artillery. The force ratio using the highest number of attackers is 6:1 PLA forces to PAVN forces. ${ }^{84}$ Colonel (Retired) T.N Dupuy, in Numbers, Predictions, and War, provides movement estimates based on historical examples. Dupuy’s research considers force ratios, type of force, type of defense, and type of terrain. Using his predictions, the estimated opposed rate of movement considering the effects of the enemy and terrain is 2.88 kilometers per day. ${ }^{85}$ An operational planner using the opposed movement calculations today would estimate fourteen days to attack the forty kilometers from the Chinese border to Cao Bang. The Chinese completely destroyed the PAVN defenders and seized Cao Bang on 25 February at a rate of five kilometers per day, indicating an impressive relative speed almost twice the historical rate of movement. ${ }^{86}$

Relative speed is one aspect of tempo, but its effect on the enemy is more relevant to testing the tempo hypothesis. Two data points illustrate the effects of tempo on PAVN forces. First, Soviet advisors recommended on 20 February an immediate airlift of 30,000 forces from Cambodia to reinforce the defense. Hanoi never responded to this recommendation, frustrating their Soviet military advisors. ${ }^{87}$ PLA tempo appeared to paralyze the Hanoi decision-making process until 3 March, the second data point. Between 3 and 5 March the PAVN decided to reconfigure their defensive forces and reinforce Lang Son. This reinforcement took from March

${ }^{84}$ O'Dowd, Chinese Military Strategy in the Third Indochina War, 58.

${ }^{85}$ Trevor N. Dupuy, Numbers, Predictions, and War: Using History to Evaluate Combat Factors and Predict the Outcome of Battles, 1985 rev. ed. (Fairfax, VA: Hero Books, 1985), 214215. 6:1 force ratio against a fortified defense in restricted terrain with poor roads is calculated as $12 \times 0.4 x 0.6=2.88 \mathrm{~km} /$ day.

${ }^{86}$ O'Dowd, Chinese Military Strategy in the Third Indochina War, 60.

${ }^{87}$ Zhang, "China's 1979 War with Vietnam,” 864. 
to July 1979, well after the Chinese withdrawal. ${ }^{88}$ Vietnam also began mobilization of the civilian population on 5 March announcing the conscription campaign within hours of China's announced withdrawal. ${ }^{89}$ The PLA not only achieved a successful tempo with respect to the enemy, but also with respect to the strategic environment.

The strategic environment constrained the PLA campaign, making tempo imperative to maintain a limited war. Chinese political leaders planned to have achieved military objectives by 2 March. ${ }^{90}$ The PLA seized the northern part of Lang Son by 2 March, but General Xu Shiyou assessed the lack of Hanoi reactions to his operations and extended the Lang Son objective south to further threaten the capital. ${ }^{91}$ Further, General Shiyou withdrew before the Soviet Union could respond militarily in Vietnam or on the Sino-Soviet border. The timing balanced the strategic objectives of affecting Hanoi with the risk of Soviet involvement. The relatively short campaign also mitigated the risk to Chinese relationships throughout the international community. In a letter dated 12 March from Chinese Premier Hua Guofeng to President Carter, China relayed, "The recent counter-attack in self-defence which China undertook against Viet Nam was a limited action of short duration, and the previously set goals have been completely attained. Our troops will complete their withdrawal to Chinese territory within a few days. I am convinced that the action was necessary and beneficial. We are satisfied with the position which you and your government took on this incident." 92 Although this letter portrayed the strategic messaging China was sending to the international community, it also reflects the effects of tempo the PLA achieved

${ }^{88}$ O'Dowd, Chinese Military Strategy in the Third Indochina War, 72.

${ }^{89}$ Zhang, "China's 1979 War with Vietnam,” 868.

${ }^{90}$ Ibid., 865.

${ }^{91}$ Ibid.

${ }^{92}$ Nickles, Foreign Relations of the United States, 831. 
in the strategic environment. China controlled the tempo to maintain the initiative and limited Vietnamese options, but lacked the depth required for overwhelming success.

Although Vietnam slowed the Chinese attack through an effective security zone and caused significant casualties, the PAVN never controlled the tempo. The PAVN formed a deadly defense; estimates of Chinese losses reach between 20,000 and 28,000 killed in action for the campaign, a casualty rate between 6.6 and 9.3 percent. ${ }^{93}$ High casualty rates however, did not force the PLA to culminate or lose the initiative.

The fourth question is how did China and Vietnam achieve depth? The answer is both China and Vietnam operated with physical depth in respect to themselves, but neither was able to affect their adversary in depth. The lack of depth in relation to the enemy denied temporal effects that could have led to shock on the military force systems. Both military forces fielded resilient forces capable of withstanding tactical failure that could not be defeated without the use of depth. The battle for Lang Son was indicative of operations conducted in depth but lacking enemy effects outside the close fight.

The PLA conducted its attack on Lang Son on a 900-kilometer front with forces assembled from over 1,000 kilometers into China. The PLA shaped the 27 February Lang Son attack with operations distributed to the north against Cao Bang, the west against Lao Cai, and locally to isolate Lang Son from the south. These operations had clear purposes to isolate Lang Son prior to the second phase of the campaign and to confuse PAVN leadership on the primary military objective. The vast distances and coordination between the distributed forces showed a physical depth with relation to time and space to achieve a purpose. However, the PLA was not able to affect PAVN forces in depth or isolate enemy forces in the close fight from reserves. There is no evidence of fires used to diminish Lang Son defenses other than in poorly coordinated

${ }^{93}$ O'Dowd, Chinese Military Strategy in the Third Indochina War, 45. 
artillery fires in support of the close fight. ${ }^{94}$ The limitations on air forces denied an important deep capability to the Chinese. The PAVN defenses of Lang Son were able to reorient after PLA successes on key terrain around Lang Son. Further, on 28 February the PAVN sent reserves from the support area in Hanoi to establish a new defensive line thirty-seven kilometers south of Lang Son. ${ }^{95}$ The Third Division that defended Lang Son conducted a withdrawal from advancing PLA forces and reorganized as a Corps reserve behind this new line after ceding the city.

PAVN forces also operated in depth with respect to friendly forces but did not achieve the temporal effects of depth on the PLA. Their defenses spanned the same 900 border kilometers as the Chinese and the distance from Hanoi to the edge of the deep area was between 160 and 280 kilometers depending on the avenue of approach. Their forces continued to support each other through these distances in maintaining a defense with multiple tactical victories. Additionally, there is evidence of a spoiling attack into China during the fight for Lang Son. PAVN forces attacked the Chinese airfield in Ningming, forty kilometers north of the border, between 17 and 28 February. ${ }^{96}$ These types of deep operations were limited to “commando” raids without air support due to the air defense capabilities of China. These raids did not significantly destroy or displace PLA lines of communication or keep PLA forces in the rear from supporting operations in the close fight.

The fifth question is how did China and Vietnam achieve operational reach? The answer is both China and Vietnam possessed the operational reach to achieve their strategic objectives. The Chinese self imposed a limited operational reach of fifty kilometers across the Vietnamese border to protect ground forces inside the PLA air defense shield. The best PLA air defense

\footnotetext{
${ }^{94}$ O'Dowd, Chinese Military Strategy in the Third Indochina War, 87.

${ }^{95}$ Ibid., 88.

${ }^{96}$ Ibid., 69.
} 
system was a surface to air missile with a slant range of fifty kilometers referred to as CSA-1 "Red Flag No. 4." ${ }^{97}$ Either the PLA did not possess the mobility to move the air defense system or they considered it too valuable to accompany forces into Vietnam. A weak logistical resupply system that relied on militia forces as porters to hand carry supplies forward along lines of communication also challenged the PLA operational reach. ${ }^{98}$ The PLA required this system to resupply an estimated daily consumption of 700 tons of ammunition and fuel..$^{99}$ The antiquated supply system and large consumption of fuel and ammunition likely contributed to the anecdotes of PLA forces at the tactical level reaching culmination due to lack of food and water. ${ }^{100}$ These logistic shortcomings did not however seem to slow the overall campaign. A pause of two days occurred between phase one and phase two of the attack from 25 to 27 February. The PLA likely took this pause one week into operations to resupply and reposition the main effort forces prior to the attack on Lang Son and did not cede the initiative to the Vietnamese. The PLA did not fail to achieve strategic or military objectives because of the fifty-kilometer air defense shield constraint or weak logistics system.

The PAVN operational reach was sufficient to conduct their defense in depth. Vietnam continued to reinforce their northern defenses after the Chinese withdrawal until July of 1979 with conscripts mobilized after 05 March. ${ }^{101}$ This allowed the PAVN to: conduct a two front war; continue operations in Cambodia and Laos; and defend against further Chinese aggression.

The last question is how did China and Vietnam achieve simultaneity? The answer is

97 Jencks, “China's “Punitive” War on Vietnam,” 809.

98 Zhang, "China's 1979 War with Vietnam,” 872.

${ }^{99}$ Ibid., 871.

${ }^{100}$ O'Dowd, Chinese Military Strategy in the Third Indochina War, 82.

${ }^{101}$ O'Dowd, Chinese Military Strategy in the Third Indochina War, 72. 
China conducted operations distributed into three separate attacks; however, converging routes into Hanoi diminished the effect of simultaneity. The simultaneous attacks had a positive effect on China's tempo. As stated previously, Vietnam reacted slowly to the initial Chinese attack because simultaneity hid the objective of the Chinese attack. ${ }^{102}$ In addition to the distributed attacks, China also conducted simultaneous information operations in Vietnamese territory to gain the support of locals. The PLA formed political units to operate in the rear area to spread propaganda. The PLA conducted these operations to protect Chinese civilians that lived in the border region and normalizing border relations by gaining the support of the Chinese civilians' Vietnamese neighbors. After the war, the PLA assessed the information operations "not only expanded our army’s political influence but also played a supporting role in the successful completion of the mission." 103

Vietnam achieved simultaneity because they successfully defended Hanoi against three distributed attacks and continued operations in Cambodia. Vietnam's simultaneity did not result in an increased ability to control the tempo of the Chinese. Vietnam never transitioned to the offense or gained the initiative in any other way. The next part of this section will link the research questions to the hypotheses.

Assessment

The research found evidence of operational art elements employed by the PLA and PAVN in the Sino-Vietnamese War. Both forces also combined parts of these elements to strengthen their operations. This combination of multiple elements is an important link of the study's hypotheses to the thesis. In addition, the combination of elements did effect the PLA and PAVN accomplishment of strategic objectives.

\footnotetext{
102 Zhang, "China's 1979 War with Vietnam,” 864.

${ }^{103}$ O'Dowd, Chinese Military Strategy in the Third Indochina War, 134.
} 
The Chinese attack negatively affected Vietnam's ability to achieve its strategic objectives. Operations in Laos and Cambodia shaped the Vietnamese approach, therefore the defense was an economy of force against China in order to achieve strategic objectives outside Vietnam. Vietnam did not need to control the tempo operationally against the Chinese, but only to slow the tempo enough to defend Hanoi with forces available. There is evidence that suggests the Chinese attack negatively influenced the operations in Cambodia. On 27 February 1979, the PAVN moved two Corps in Cambodia conducting operations against the Khmer Rouge to pursue the PLA to the Chinese border. ${ }^{104}$ Although the PAVN retasked these forces from their initial mission, evidence does not suggest this forced a change in the Vietnamese overall approach in Cambodia. Vietnam emplaced a complex area defense, with up to 280 kilometers of depth along three not supporting avenues of approach. This resulted in a resilient PAVN force able to withstand the PLA attack without threatening the capital. Operationally, Vietnam defended simultaneously across a 900-kilometer front and further had simultaneity strategically. Finally, Vietnam arranged tactical actions within its available operational reach. China threatened Vietnam's ability to maintain all operations however, resulting in the mass mobilization efforts that began 5 March.

China's tactics achieved their strategic objectives of eliminating external vulnerabilities and consolidating internal power around Vice-Premier Deng Xiaoping. The PLA nested the purpose of tactical actions to control the tempo of the attack. Their ability to achieve simultaneity in their actions on three separate axes of attack also assisted in controlling tempo. The PLA constrained the depth of actions to fifty kilometers in order to maintain air defense coverage from SAM sites inside China. Although the Chinese operated with tremendous depth from the close to

${ }^{104}$ Merle L. Pribbenow, "A Tale of Five Generals: Vietnam's Invasion of Cambodia," The Journal of Military History 70, no. 2 (2006): 459-86, accessed February 14, 2014, http://dx.doi.org/10.1353/jmh.2006.0121.485. 
rear fight, they were not able to achieve depth in relation to the PAVN. PLA operational reach, affected by available ADA coverage and a crude supply system, limited the Chinese operational approach with a fifty-kilometer constraint. The PLA did possess the operational reach to maintain the initiative within the constraint.

This section examined the case study of the Sino-Vietnamese War to determine the validity of the four hypotheses. The strategic context and operational overview provided the necessary background to understand the larger context of the war. The research questions focused the examination of tactical actions to identify how their arrangement allowed China and Vietnam to achieve strategic objectives. Finally, an assessment of the research questions found the operational art theoretical framework was evident in Chinese operations. The next section will complete the structured, focused comparison methodology by analyzing the findings of the case study. 


\section{Findings and Analysis}

This section analyzes the use of operational art in the Sino-Vietnamese War to achieve strategic objectives and determines the findings of the hypotheses. The Chinese employed operational art in the Sino-Vietnamese War because it combined tempo, simultaneity, and operational reach in an attempt to achieve its strategic objectives. The war was a limited offensive initiated by China to eliminate external vulnerabilities and consolidate internal power after the Cultural Revolution. An assessment of China’s success in achieving strategic objectives requires the examination of both countries overall aims. This section consists of two parts. The first part determines China and Vietnam's ability to achieve their overall aims through the operational art theoretical framework. The second part is an analysis of the four hypotheses.

\section{Findings}

China's overall aim during the Sino-Vietnamese War was to consolidate internal power in order to modernize the Chinese society and to eliminate external vulnerabilities. Internally, the Fifth Plenum in February 1980 replaced Chinese leaders that opposed Vice Premier Deng Xiaoping and set into motion the modernization programs that changed the future of the nation. ${ }^{105}$ Strong evidence supports that the Sino-Vietnamese War contributed in consolidating internal power. The question remains, did China succeed in eliminating external vulnerabilities?

China viewed external vulnerabilities in 1979 differently depending on the actor. The unifying idea is China decreases external threats by disrupting regional alliances. China's relative power and strategic advantage is best when compared to one country at a time, and the aim of the Sino-Vietnamese War was to fracture regional alliances. Chinese strategic objectives achieved their aim by degrading the Soviet Union's alliance with Vietnam and by denying Vietnam’s ability to unite Laos and Cambodia into an Indochina Federation.

\footnotetext{
${ }^{105}$ Henry Kissinger, On China, Reprint ed. (New York: Penguin Books, 2012), 339.
} 
The Soviet Union's alliance with Vietnam and influence in the region was the largest threat to China's regional interests. This interest aligned directly with US interests and resulted in increased cooperation between the two nations. On 11 March 1978, Secretary of Defense Brown sent President Carter a memorandum suggesting a response to Soviet aggression by “initiating talks with the PRC (People’s Republic of China) on matters of common interest." ${ }^{106}$ China was able to use these aligned interests to cooperate against the Soviet Union and to change US behavior towards Taiwan. This resulted in China achieving another strategic aim when the US ended diplomatic relations with Taiwan and officially recognized the People’s Republic of China on 01 January 1979. ${ }^{107}$ Vice-Premier Deng Xiaoping referred to Vietnam as “one hundred percent the Cuba of the East” in his 29 January 1979 meeting with President Carter. ${ }^{108}$ The Vietnamese treaty with the Soviet Union unified two nations hostile to China. The Sino-Vietnamese War successfully showed the Soviet Union would not fully support Vietnam and damaged Soviet influence in the region. Henry Kissinger describes the Sino-Vietnamese War as a turning point in the Cold War since the Soviet Union did not respond to a clear attack against Soviet interests and the three-month old treaty. ${ }^{109}$

China did deny Vietnam's efforts to unite Laos and Cambodia into an Indochinese Federation, however the impacts of the Sino-Vietnamese War strategic objectives on this aim is less clear. Evidence suggests that the strategic objective of diverting Vietnamese pressure on Cambodia changed during the war, and that this change affected China's ability to achieve depth. First, changing Vietnamese behavior in Cambodia and Laos appeared as the initial strategic

\footnotetext{
${ }^{106}$ Nickles, Foreign Relations of the United States, 300.

${ }^{107}$ Ibid., 688.

${ }^{108}$ Ibid., 768.

${ }^{109}$ Kissinger, On China, 341.
} 
objective for China as relayed by Vice-Premier Deng Xiaoping to President Carter in the same 29 January 1979 meeting in Washington D.C. ${ }^{110}$ The objective changed after the war to maintaining a viable threat to Vietnam's interests in Cambodia through the Khmer Rouge insurgency. ${ }^{111}$ Chinese military failures to threaten Hanoi enough to force a large-scale withdrawal of forces from Cambodia resulted in the change of objectives. The next piece of evidence is reflected in Vice Premier Deng Xiaoping confiding to Kissinger a month after the war, "in retrospect, we think if we had driven deeper into Vietnam in our punitive action, it would have been even better... we could have driven thirty kilometers deeper into Vietnam.” ${ }^{112}$ China had to balance the two strategic objectives to achieve their overall aim of breaking alliances between states in the region.

The Chinese neglected achieving depth, changed one strategic objective and prioritized another, to achieve their overall aim. The risk to the Chinese was catastrophic success in destroying the Vietnamese Army through depth and forcing a Soviet military response. The evidence shows the lack of depth was a deliberate decision by the Chinese in an attempt to keep the war limited. This is also one of the primary reasons for criticism of the Chinese military action. However, as Kissinger quotes Singapore’s Prime Minister Lee Kuan Yew, “the Western press wrote off the Chinese punitive action as a failure. I believe it changed the history of East Asia.” ${ }^{113}$

Vietnam's primary aim was to consolidate control over Cambodia and Laos to establish regional power in Southeast Asia. This strategy relied on Soviet Union support to balance

\footnotetext{
${ }^{110}$ Nickles, Foreign Relations of the United States, 768.

${ }^{111}$ Ibid., 982.

${ }^{112}$ Kissinger, On China, 370.

${ }^{113}$ Kissinger, On China, 376.
} 
Chinese influence and provide necessary resources. China isolated Vietnam by damaging its link with the Soviet Union. Vietnam successfully arranged tactical actions in time, space and purpose to achieve strategic objectives but achieved limited success. After the Chinese strategy became clear, Vietnam required a similar reframing of strategic objectives to bring greater Soviet support into the war. This reframing did not appear to occur, resulting in Vietnam falling into greater isolation. Vietnam continued to follow the same strategy throughout the 1980's, simultaneously fighting for control of Indochina and massing enough forces on the Chinese border to defend against further attacks. This strategy required increased support from the Soviet Union, support Vice-Premier Deng Xiaoping predicted the Soviets could not sustain. ${ }^{114}$

\section{Analysis}

The first hypothesis states that when Vietnam and China achieve tempo they achieve their strategic objectives. The evidence supports this hypothesis. China achieved a tempo in the campaign that supported their strategic objectives. The tempo also fit the multi-faceted strategic environment for China and Vietnam. Although China set the tempo, Vietnam responded in a way that also met their strategic objectives of uninterrupted operations in Cambodia and the successful defense of Hanoi.

The second hypothesis states that when Vietnam and China achieve depth they achieve their strategic objectives. The evidence does not support this hypothesis. Neither country achieved depth in relation to the enemy. The lack of depth negatively affected both actors ability to achieve their strategic objectives. This affected China's ability to force Vietnam to withdraw from Cambodia and required a reframing of strategic objectives. China purposely restricted the PLA's use of depth to balance strategic objectives between discrediting Soviet Union support of Vietnam and denying the formation of the Vietnamese desired Indochinese Federation. Lack of

114 Ibid., 374. 
depth also affected Vietnam's ability to attack the PLA limited offensive approach and bring the Soviet Union into the war. Both forces however were resilient to tactical failures because of their depth in relation to friendly operations.

The third hypothesis states when Vietnam and China achieve operational reach they achieve their strategic objectives. The evidence partially supports the hypothesis. The PLA's archaic supply system and the available fifty-kilometer ADA coverage limited their operational reach. Operational reach limited the depth that China was able to achieve and was an important factor in China reframing their strategic objectives. Vietnam's operational reach was sufficient to maintain their two-front conflict.

The fourth hypothesis states that when Vietnam and China achieved simultaneity they achieve their strategic objectives. The evidence supports the hypothesis. China’s simultaneity resulted in achieving their military objective of seizing Lang Son with a positive effect on their strategic objectives. Vietnam's simultaneity resulted in Vietnam maintaining operations in Cambodia and defending Hanoi and resulted in increased regional power. Simultaneity was a critical component of both Armies’ ability to achieve tempo.

This section presented the findings that link the hypotheses to the case study evidence and the analysis of China and Vietnam's ability to achieve strategic objectives through the operational art theoretical framework. The use of operational art was evident, however success required the actors to reframe strategic objectives after the war changed the environment. Both forces required the agility to change objectives after operational already began. China was agile enough to change, and adjusted to achievable military objectives therefore ending combat operations and entering negotiations in May 1979 with a greater relative advantage in the region. The next section will conclude by evaluating the thesis with respect to the hypotheses findings. 


\section{Conclusion}

This study examined the Sino-Vietnamese War to gain an increased understanding of how the People’s Liberation Army of China and the People’s Army of Vietnam conducted a land campaign to achieve their strategic objectives. The limited offensive in 1979 by the PLA fit the Chinese pattern of behavior set by the Korean War, the Sino-Indian War in 1962, the Sino-Soviet War of 1969 and recent actions in the South China Sea. Each used limited military force to contest threats to Chinese sovereignty and increase regional Shih. Specifically, Chinese leadership viewed regional alliances as external vulnerabilities that demanded action. The study focused on research questions necessary to evaluate actions within the operational art theoretical framework. The first question identified the strategic objectives of both actors, a requirement to begin an operational art analysis. The second question identified the strategic approach used by China and Vietnam to achieve their objectives. The third question began the analysis of elements of operational art and asked how China and Vietnam achieved tempo. The fourth question asked how both actors achieved depth. The fifth question asked how China and Vietnam achieved operational reach. The final research question asked how China and Vietnam achieved simultaneity. The questions focused the examination on the specific tactical actions arranged in time, space and purpose to achieve strategic objectives.

China conducted operational art by arranging tactical actions to achieve their strategic objectives in the Sino-Vietnamese War. The evidence supports three of the four hypotheses and the thesis overall. China used tempo, operational reach and simultaneity to achieve their strategic objectives. The hypothesis when depth is achieved then Vietnam and China achieve their strategic objectives was not supported by the evidence. The study also found the hypotheses have a relation with each other. Simultaneity was a necessary condition for tempo and operational reach was critical to achieve depth. A relationship also exists between depth and a limited war approach. Extending operations in space, time and purpose threatens the destruction of the 
opposing actor's military forces and therefore elevates limited war objectives towards total war. The Sino-Vietnamese War case study provides historical evidence for future operational planners to consider the adverse relationship of depth to limited objectives. Operations in depth can result in catastrophic success that threatens limited objectives by destroying an actor's military power.

The Sino-Vietnamese War is significant to future military planners in the region because it establishes a pattern of behavior for Chinese use of force and how the PLA arrange tactical actions to achieve strategic objectives. Regional alliances are a key indicator for the Chinese use of force. The study is significant to military planners in any region because it shows the importance of reframing strategic objectives after operations begin and the relationship of depth to achieve limited objectives. The study did not examine, in detail, significant changes to the PAVN operational approach in either Cambodia or Laos because of the Chinese attack. This gap exists because of the lack of Vietnamese sources to how the PAVN conducted its strategy in Cambodia and Laos from 1978 to 1989. The research identifies other areas to study including the PLA use of operational art in other border wars, Eastern approaches to limited wars, and further examination into the link between depth and limited war. The use of cyber power to achieve depth in limited war without risking catastrophic success is also a relevant study for future military planners. Another area for future study is to examine the modernization that occurred in the PLA after the Sino-Vietnamese War and how this modernization may result in possible changes in Chinese operational approaches. Finally, this case highlighted cooperation between China and the United States when national interests coincided, and challenges operational planners to look for similarities instead of differences in future Phase Zero planning. 


\section{Bibliography}

Army Doctrine Publication 3-0, Unified Land Operations. Washington DC: Government Printing Office, 2011.

Army Doctrine Reference Publication 3-0, Unified Land Operations. Washington DC: Government Printing Office, 2012.

Chen, King C. China's War with Vietnam, 1979: Issues, Decisions, and Implications. Stanford, Calif.: Hoover Institution Press, Stanford University, 1987.

Clausewitz, Carl von. On War. Translated by Michael Howard, Peter Paret, and Bernard Brodie. Princeton, NJ: Princeton University Press, 1984.

Craig, Susan L. Chinese Perceptions of Traditional and Nontraditional Security Threats. Carlisle, PA: Strategic Studies Institute, US Army War College, 2007.

Dupuy, Trevor N. Numbers, Predictions, and War: Using History to Evaluate Combat Factors and Predict the Outcome of Battles. 1985 rev. ed. Fairfax, Va.: Hero Books, 1985.

Elleman, Bruce A. Modern Chinese Warfare, 1795-1989. Warfare and History. London: Routledge, 2001.

Gilks, Anne. China Research Monograph. Vol. 39, The Breakdown of the Sino-Vietnamese Alliance, 1970-1979. Berkeley: Institute of East Asian Studies, University of California, Center for Chinese Studies, 1992.

Hood, Steven J. Dragons Entangled: Indochina and the China-Vietnam War. Armonk, N.Y.: M.E. Sharpe, 1992.

Isserson, G S. The Evolution of Operational Art. 2nd ed. Translated by Bruce Menning. Fort Leavenworth, KS: Combat Studies Institute Press, US Army Combined Arms Center, 2013.

Jencks, Harlan W. “China's "Punitive” War on Vietnam: A Military Assessment.” Asian Survey 19, no. 8 (August 1979): 801-15. Accessed July 10, 2014. http://dx.doi.org/10.1525/as.1979.19.issue-8.

Joint Publication JP 1-02. Department of Defense Dictionary of Military and Associated Terms. Washington, DC: Government Printing Office, 2012.

Kissinger, Henry. On China. Reprint Ed. New York: Penguin Books, 2012.

Lai, David. Learning from the Stones: A Go Approach to Mastering China's Strategic Concept, Shi. Advancing Strategic Thought Series. Carlisle, PA: Army War College, Strategic Studies Institute, 2004.

Leonhard, Robert R. Fighting by Minutes: Time and the Art of War. Westport, CT: Praeger, 1994.

McGregor, Charles. The Sino-Vietnamese Relationship and the Soviet Union. Adelphi Papers 232. London: The International Institute for Strategic Studies, 1988. 
Mott, William H., and Jae Chang Kim. The Philosophy of Chinese Military Culture: Shih Vs. Li. New York, N.Y.: Palgrave Macmillan, 2006.

Naveh, Shimon. The Cummings Center Series, Vol. 7, In Pursuit of Military Excellence: the Evolution of Operational Theory. London: Frank Cass, 1997.

Nguyen-Vo, Thu-Huong. Khmer-Viet Relations and the Third Indochina Conflict. Jefferson, N.C.: McFarland, 1992.

Nickles, David Paul. Foreign Relations of the United States 1977-1980. Volume XIII, China. Washington: United States Government Printing Office, 2013.

O'Dowd, Edward C. Chinese Military Strategy in the Third Indochina War: The Last Maoist War. Asian Security Studies. London: Routledge, 2007.

Pillsbury, Michael. China Debates the Future Security Environment. Washington, DC: National Defense University Press, 2000.

Pribbenow, Merle L. "A Tale of Five Generals: Vietnam's Invasion of Cambodia." The Journal of Military History 70, no. 2 (2006): 459-86. Accessed February 14, 2014. http://dx.doi.org/10.1353/jmh.2006.0121.

Ross, Robert S. The Indochina Tangle: China's Vietnam Policy, 1975-1979. Studies of the East Asian Institute. New York: Columbia University Press, 1988.

Schneider, James J. Vulcan's Anvil: The American Civil War and the Foundations of Operational Art. Fort Leavenworth: Presidio Press, 1994.

Scobell, Andrew. China and Strategic Culture. Carlisle, PA: Strategic Studies Institute, U.S. Army War College, 2002.

Sterling, Eleanor Jane, Martha Maud Hurley, and Le Duc Minh. Vietnam: a Natural History. New Haven: Yale University Press, 2006.

Sunzi. Sun-tzu: The Art of Warfare. Classics of Ancient China. New York: Ballantine Books, 1993.

Tajima, Takashi. Adelphi Papers, Vol. 172, China and South-East Asia: Strategic Interests and Policy Prospects. London: International Institute for Strategic Studies, 1981.

Tse-Tung, Mao. Selected Military Writings of Mao Tse-Tung. Peking: Foreign Languages Press, 1972.

Westad, Odd Arne, and Sophie Quinn-Judge, eds. Cold War History. Vol. 11, The Third Indochina War: Conflict between China, Vietnam and Cambodia, 1972-79. New York: Routledge, 2006. 
Wickberg, Edgar. Historical Interaction of China and Vietnam: Institutional and Cultural Themes. International Studies, East Asian Series Research Publication, No. 4. Lawrence: Center for East Asian Studies, University of Kansas: Paragon Book Gallery, New York, 1969.

Whitman, Hilary. "How an oil rig sparked anti-China riots in Vietnam.” Cable News Network, May 19, 2014. Accessed July 10, 2014. http://www.cnn.com/2014/05/19/world/asia/chinavietnam-islands-oil-rig-explainer/index.html?iref=allsearch.

Zhang, Xiaoming. “China's 1979 War with Vietnam: A Reassessment.” The China Quarterly 184, No. 1 (December 2005): 851. Accessed July 10, 2014. http://dx.doi.org/10.1017/S0305741005000536. 